\title{
In Premature Newborns
} Intraventricular Hemorrhage Causes Cerebral Vasospasm and Associated Neurodisability via Heme-Induced Inflammasome-Mediated Interleukin-1 Production and Nitric Oxide Depletion

\author{
Michael Eisenhut* and Samyami Choudhury \\ Pediatric Department, Luton and Dunstable University Hospital NHS Foundation Trust, Luton, Bedfordshire, United Kingdom
}

OPEN ACCESS

Edited by:

Guillaume Sébire,

McGill University, Canada

Reviewed by:

Susan Cohen,

Medical College of Wisconsin,

United States

Brahim Tabarki,

University of Sousse, Tunisia

*Correspondence:

Michael Eisenhut

michael.eisenhut@talk21.com

Specialty section: This article was submitted to

Neuropediatrics,

a section of the journal

Frontiers in Neurology

Received: 17 June 2017 Accepted: 04 August 2017 Published: 18 August 2017

Citation: Eisenhut M and Choudhury S (2017) In Premature Newborns Intraventricular Hemorrhage Causes Cerebral Vasospasm and Associated

Neurodisability via Heme-Induced Inflammasome-Mediated Interleukin-1

Production and Nitric Oxide Depletion.

Front. Neurol. 8:423.

doi: 10.3389/fneur.2017.00423
Background: Intraventricular hemorrhage (IVH) occurs in 60-70\% of neonates weighing 500-750 $\mathrm{g}$ and 10-20\% of those weighing 1,000-1,500 g. All forms of IVH have been associated with neurocognitive deficits. Both subarachnoid and IVHs have been associated with delayed vasospasm leading to neurological deficits. Pathways linking hemoglobin release from blood clots to vasospasm include heme-induced activation of inflammasomes releasing interleukin-1 (IL-1) that can cause calcium dependent and independent vasospasm. Free hemoglobin is a potent scavenger of nitric oxide (NO). Depletion of NO, a potent endogenous vasodilator, has been associated with features of vasospasm.

Hypothesis: In premature newborns, IVH causes cerebral vasospasm and associated neurodisability via heme-induced increased inflammasome-mediated IL-1 production and NO depletion.

Confirmation of hypothesis and implications: This hypothesis could be confirmed in the IVH animal model with visualization of any associated vasospasm by angiography and in newborns with IVH by transcranial Doppler ultrasonography and correlation with cerebrospinal fluid IL-1 and NO metabolite levels. Confirmation of the role of heme in activation of inflammasomes causing $\mathrm{IL}-1$ production and $\mathrm{NO}$ binding could be achieved by measuring the effect of heme scavenging interventions on IL-1 levels and levels of NO metabolites. In addition to removal of the accumulated blood of an IVH by drainage, irrigation, and fibrinolytic therapy intrathecal application of vasodilators and heme scavenging agents like haptoglobin and haemopexin and systemic treatment with inhibitors of inflammasomes like telmisartan could be used to prevent and treat cerebral vasospasm, and thus reduce the risk of associated brain injury in premature neonates.

Keywords: hemorrhage, vasospasm, heme, inflammasome, nitric oxide, interleukin-1 


\section{INTRODUCTION}

Arterial development is completed initially in brainstem and cerebellum (20-24 weeks) followed by the basal ganglia and diencephalon by 24-28 weeks and finally the cortex and germinal matrix. Rupture of fragile capillaries in the subependymal germinal matrix can give rise to intraventricular hemorrhage (IVH). Immaturity of the cerebral vasculature in the border zones between vascular territories makes the preterm brain vulnerable to bleeding (1). The immature vasoregulation coupled with rises in arterial pressure due to the stresses of postnatal adaption after extreme premature delivery contributes to the pathogenesis of IVH. IVH occurs 12-72 h after birth (2). IVH causes significant morbidity and mortality in the preterm infant group. IVH occurs in $60-70 \%$ of neonates weighing $500-750 \mathrm{~g}$ and $10-20 \%$ of those weighing 1,000-1,500 $\mathrm{g}$ (3). IVH can be divided into four degrees of severity according to Papile (4):

- Grade I-bleeding occurs just in the germinal matrix.

- Grade II-bleeding also occurs inside the ventricles, but they are not enlarged.

- Grade III-ventricles are enlarged by the accumulated blood.

- Grade IV-bleeding extends into the brain tissue around the ventricles.

Prematurity and low birth weight are the most important risk factors for grade IV hemorrhage. Other risk factors for IVH identified include the absence of prenatal steroid therapy in woman at risk of premature delivery, symptoms of intrauterine infection in the newborn, treatment with fluid boluses and catecholamines for hypotension and treatment for metabolic acidosis, blood clotting disorders, thrombocytopenia, and hypoglycemia. Most of the mentioned risk factors are associated with a systemic inflammatory response involving cytokine release (5). Preterm infants with grade IV IVH are at the high risk of developing neuropathological complications including posthemorrhagic hydrocephalus, periventricular hemorrhagic infarction, germinal matrix destruction, and periventricular leukomalacia. This leads to significant neurodevelopmental morbidity. In one casecontrol study of 1,472 infants with a history of preterm delivery (23-28 weeks gestational age at birth), those with grade III-IV IVH had significantly increased rates of cerebral palsy $(30 \%)$, developmental delay (17.5\%), deafness (8.6\%), and blindness (2.2\%). Infants with grade I-II IVH also had compared with infants without IVH increased rates of neurosensory impairment (22 vs $12.1 \%$ ), cerebral palsy (10.4 vs 6.5\%), developmental delay (7.8 vs $3.4 \%$ ), and deafness (6.0 vs $2.3 \%$ ) (1). The fact that lower degrees of IVH are also associated with significant neurological morbidity was confirmed by Patra et al. who found that infants who have extremely low birth weight with grades I-II IVH had poor neurodevelopmental outcomes at 20 months than infants with normal cranial ultrasound (6).

The consequences of extravasated blood around blood vessels are evident from what we have learnt about the pathophysiology of brain injury in subarachnoid hemorrhage (SAH) $(7,8)$. Extravasated red blood cells release on disintegration free hemoglobin which acts as a nitric oxide (NO) scavenger (7). NO, which is generated from $\mathrm{L}$-arginine by endothelial NO synthase stimulates soluble guanylate cyclase in vascular muscle resulting in an increase in the intracellular concentration of guanosine $3^{\prime}, 5^{\prime}$-cyclic monophosphate resulting in relaxation of vascular smooth muscle (9). NO depletion subsequently leads to vasoconstriction causing ischemia and subsequent tissue injury (7).

Free heme and tissue injury trigger a localized inflammatory response involving inflammasome namely, nucleotide-binding and oligomerization domain-like receptor pyrin domaincontaining protein 3 (NLRP3) activation (10). Heme activates NLRP3 through P2X receptors, especially the P2X7R and P2X4R. The molecular mechanism by which heme promotes NLRP3 activation in the presence of serum requires Syk phosphorylation, reactive oxygen species, and $\mathrm{K}^{+}$efflux. NLRP3 activation then leads to increased production of interleukin-1 (IL-1) in macrophages. All forms of neuroinflammation that involves production of IL-1 have been, where this has been investigated, shown to be associated with cerebral vasospasm (11).

Interleukin-1 induces the production of IL-6. Increased concentrations of IL-6 in the cerebrospinal fluid were found to be associated with white matter injury in premature infants (12).

Interleukin-1 has been shown to cause vasoconstriction by calcium dependent and independent mechanisms. Investigations in patients with SAH showed that CSF levels of IL-1-beta were increased and correlated with the later development of cerebral vasospasm. IL-1 acts through G-protein-coupled receptors by activation of intracellular phospholipase $\mathrm{C}$ and phospholipase mediated protein kinase $\mathrm{C}$ (PKC) activation (11):

1. Phosphatidylinositol trisphosphate produced by phospholipase $\mathrm{C}$ activity leads to calcium release that causes myosin light chain (MLC) kinase activation triggering MLC activation and calcium-dependent vasospasm.

2. Activation of PKC through diacylglycerol generated by phospholipase C action from phosphatidylinositol $(4,5)$ bisphosphate can act through phosphorylation and hence activation of the MLC kinase. Prolonged contraction of blood vessels lasting up to 2 weeks has been found to be related to this mechanism.

3. MLC phosphorylation subsequent to PKC activation is increased through activation of rho-kinase and the myosinbinding subunit (MBS) of MLC phosphatase (MLCPh). Rho-kinase hereby phosphorylates MBS, which results in the inhibition of MLCPh. The reduced MLCPh activity is associated with increased phosphorylation and hence contractility of the MLC resulting in calcium-independent vasospasm. There is a highly significant correlation between the extent of MBS phosphorylation and contractions.

\section{HYPOTHESIS}

In premature newborns, IVH causes cerebral vasospasm and associated neurodisability via heme-induced increased inflammasome-mediated IL-1 production and NO depletion.

\section{Explanation of Hypothesis}

This hypothesis states that the effects of breakdown products of extravasated red blood cells cause contraction of blood vessels at 
the arterial side of the circulation and that this contraction causes a lack of blood supply leading to neuronal cell death causing permanent brain injury and resulting neurodisability. Previous theories attributed brain injury after hemorrhage mainly to ischemia from rupture of nutrient vessels, stasis of blood flow from disruption of venous drainage, ischemia from a pressure effect exerted by the extravasated blood or blockage of cerebrospinal fluid drainage, and cytotoxic effects of the posthemorrhagic inflammatory response $(13,14)$.

These effects may be present and contributory to brain damage but are with the exception of measures to reduce intracranial pressure largely inaccessible to therapeutic interventions and reversible factors like vasospasm need to be explored to find ways of improving outcome. Vasospasm is a reversible cause of ischemia and can be addressed by preventative and therapeutic interventions.

\section{EVIDENCE TO SUPPORT THE HYPOTHESIS}

- In patients with SAH, additional grade IV IVH is significantly associated with ultra-early angiographic vasospasm, which was associated with symptoms, delayed cerebral ischemia and infarction, unfavorable outcome at follow-up, and greater mortality (15).

- Using transcranial Doppler ultrasound evidence of cerebral vasospasm has been detected in all forms of IVH, including those arising from hypertension under the influence of anticoagulant and antithrombotic agents and arteriovenous malformations (AVM). This supports the hypothetical assumption that not the process causing the bleeding but the blood itself is involved in causing the cerebral vasospasm. In adults above 50 years of age, cerebral vasospasm was common in IVH and occurred in $62.9 \%$ of patients $(n=62)$ on serial transcranial Doppler ultrasound scanning that was performed at $48 \mathrm{~h}$ between day 4 and 6 and between day 7 and 9 after diagnosis of IVH including insonation of the middle, anterior, and posterior cerebral arteries as well as the siphon, vertebral arteries in the V4 segment and the basilar artery with a grading according to peak systolic velocity (16). In a study using stricter criteria for cerebral vasospasm including in addition to the velocity criteria, the Lindegaard ratio (ratio $>3$ in middle cerebral artery flow to internal carotid artery flow as indicator of cerebral vasospasm) about $6 \%$ of patients with IVH were found to have vasospasm (17).

- Detailed descriptions of the characteristics of vasospasm and treatment attempts are available from case reports. There are 13 previous reports of cerebral vasospasm associated with IVH as complication of ruptured AVMs including several without SAH (see Table 1). In one child with IVH early fever was found to be a predictor of vasospasm similar to what has been observed in patients with $\mathrm{SAH}$, which supports the role of inflammation and the endogenous pyrogen IL-1 in causing the vasospasm found (18). The lack of success of calcium antagonists in reducing vasospasm as reported in case reports (see Table 1) and lack of influence on outcome of intracerebral bleeds may be due to the fact that IL-1 caused vasospasm predominantly through a calcium-independent pathway.

- If inflammasome-induced IL-1 causes vasospasm-induced brain injury, there should be brain injury associated with sterile brain inflammation in preterm neonates with a systemic inflammatory response syndrome not associated with meningitis. This has been indeed confirmed. Preterm neonates with early onset clinical sepsis without meningitis had in $22 \%$ evidence of white matter damage on MRI. The neonates with death or abnormal neuroimaging as outcome had significantly higher cerebrospinal IL-1 levels (19).

- The effect of IVH on vasospasm in arteries remote from the location of the IVH is consistent with one or more mediators carried by the CSF and transmitting this effect from the blood clot to the arteries. The delayed onset of vasospasm after IVH would be consistent with a threshold of the concentration of mediators in the CSF above or below which vasoconstriction occurs. Vasospasm could also depend on both duration of effect and quantity of the mediator involved. The CSF circulation could hereby modulate the concentration of any mediators involved; Black previously reported a significant association between hydrocephalus and vasospasm in patients with $\mathrm{SAH}$; in $62 \%$ of cases, vasospasm and hydrocephalus occurred concomitantly and in $11 \%$ of patients, vasospasm was not associated with hydrocephalus (20). The fact that the quantity of the mediator is crucial in triggering the vasospasm is supported by the observed correlation of the quantity of blood injected in an experimental model of SAH and vasospasm (21).

- The potent vasodilator inhaled NO given to support pulmonary blood flow and improve oxygenation in newborns with severe respiratory failure has been shown to improve neurodevelopmental outcome at 2 and at over 5 years of age mainly due to a $47 \%$ decrease in the risk of cognitive impairment (defined by a score of less than 70 on the Bayley Mental Developmental Index $)(p=0.03)(22,23)$.

- The potent smooth muscle relaxant intravenous magnesium sulfate when given antenatally to mothers is partially responsible for reduction of ultrasonic evidence of cerebral injury in preterm infants less than 32 weeks gestation and cerebral palsy at 2 years of age (24).

\section{EVIDENCE AGAINST THE HYPOTHESIS}

- A recent Cochrane review on the impact of the vasodilator inhaled $\mathrm{NO}$ on the outcome of respiratory failure in preterm neonates found no impact of its use on long-term neurodisability (36).

- Any effects of NO on neurodisability may not have been due to influence on vasospasm but simply have been due to improved cerebral oxygenation (37).

- The influence of magnesium sulfate on cerebral lesions and cerebral palsy may have been due to improved placental perfusion (38).

- Intravenous application of the vasodilating calcium antagonist nicardipine lowering blood pressure in patients with intracerebral hemorrhage and able to penetrate the blood-brain barrier did not improve neurological outcome in adults (39). 
TABLE 1 | Characteristics of patients with intraventricular hemorrhage (IVH) as complication of arteriovenous malformation who had cerebral vasospasm detected.

\begin{tabular}{|c|c|c|c|c|c|c|c|}
\hline $\begin{array}{l}\text { Age } \\
\text { (years) }\end{array}$ & Type of hemorrhage & $\begin{array}{l}\text { Method } \\
\text { involved in } \\
\text { detection of } \\
\text { vasospasm }\end{array}$ & Blood vessel involved in vasospasm & $\begin{array}{l}\text { Timing of } \\
\text { vasospasm }\end{array}$ & $\begin{array}{l}\text { Medication used to treat vasospasm and } \\
\text { effect }\end{array}$ & Features of neurodisability & Reference \\
\hline 11 & $\begin{array}{l}\text { Isolated IVH in lateral, third, } \\
\text { and fourth ventricle }\end{array}$ & $\begin{array}{l}\text { Cerebral } \\
\text { angiography }\end{array}$ & $\begin{array}{l}\text { A1 and M1 segments of both anterior and } \\
\text { middle cerebral arteries }\end{array}$ & Day 4 & $\begin{array}{l}\text { Corticosteroids, osmotherapy with glycerol } \\
\text { without effect }\end{array}$ & $\begin{array}{l}\text { Right sided hemiparesis, } \\
\text { speech disturbance and right } \\
\text { hemianopsia }\end{array}$ & $\begin{array}{l}\text { Yanaka } \\
\text { et al. (25) }\end{array}$ \\
\hline 31 & $\begin{array}{l}\text { IVH and intracerebral } \\
\text { hemorrhage in corpus } \\
\text { callosum }\end{array}$ & $\begin{array}{l}\text { Cerebral } \\
\text { angiography }\end{array}$ & $\begin{array}{l}\text { Supraclinoid portion of bilateral internal } \\
\text { carotid arteries, bilateral anterior, and } \\
\text { middle cerebral arteries }\end{array}$ & Day 13 & $\begin{array}{l}\text { Papaverine, intravenous nimodipine without } \\
\text { effect }\end{array}$ & $\begin{array}{l}\text { Hydrocephalus, bilateral } \\
\text { motor weakness }\end{array}$ & $\begin{array}{l}\text { Park } \\
\text { et al. (26) }\end{array}$ \\
\hline 41 & $\begin{array}{l}\text { Isolated IVH in both lateral } \\
\text { ventricles }\end{array}$ & $\begin{array}{l}\text { Magnetic } \\
\text { resonance } \\
\text { angiography, } \\
\text { cerebral } \\
\text { angiography }\end{array}$ & $\begin{array}{l}\text { Bilateral middle cerebral arteries, right } \\
\text { anterior cerebral artery, left supraclinoid } \\
\text { internal carotid artery, basilar artery, and } \\
\text { bilateral posterior cerebral arteries }\end{array}$ & Day 10 & $\begin{array}{l}\text { Verapamil intra-arterial in right and left internal } \\
\text { carotid with immediate clinical improvement and } \\
\text { vertebral arteries, nimodipine }\end{array}$ & $\begin{array}{l}\text { Right hemineglect, left-gaze } \\
\text { preference, mild right-facial } \\
\text { droop }\end{array}$ & $\begin{array}{l}\text { Gerard } \\
\text { et al. (27) }\end{array}$ \\
\hline 33 & $\begin{array}{l}\text { Isolated IVH in lateral and } \\
\text { fourth ventricles }\end{array}$ & MR angiography & $\begin{array}{l}\text { Supraclinoid portions of the bilateral } \\
\text { internal carotid arteries and the } \\
\text { supraclinoid, A1 and distal portions of the } \\
\text { anterior cerebral arteries }\end{array}$ & Day 17 & $\begin{array}{l}\text { Intravenous calcium antagonists, radical } \\
\text { scavengers, and volume expanders with no } \\
\text { success }\end{array}$ & $\begin{array}{l}\text { Reduced verbal response } \\
\text { and motor aphasia, mild right } \\
\text { sided hemiparesis }\end{array}$ & $\begin{array}{l}\text { Yokobori } \\
\text { et al. (28) }\end{array}$ \\
\hline 37 & $\begin{array}{l}\text { IVH in all four ventricles and } \\
\text { thalamic bleed }\end{array}$ & Perfusion CT & Diffuse cerebral vasospasm & Day 10 & $\begin{array}{l}\text { Intravenous then oral nimedipine, intravenous } \\
\text { norepinephrine, intrathecal urokinase, and } \\
\text { ventricular drainage without effect }\end{array}$ & $\begin{array}{l}\text { Transient left sided } \\
\text { hemiparesis and speech } \\
\text { impediment }\end{array}$ & $\begin{array}{l}\text { Tseng and } \\
\text { Tsai (29) }\end{array}$ \\
\hline 40 & $\begin{array}{l}\text { Right thalamic and IVH in all } \\
\text { four ventricles }\end{array}$ & $\begin{array}{l}\text { Cerebral } \\
\text { angiogram }\end{array}$ & $\begin{array}{l}\text { Supraclinoid portion of both internal } \\
\text { carotid arteries }\end{array}$ & Day 6 & Induced hypertension with volume expansion & $\begin{array}{l}\text { Persistent right sided mild } \\
\text { hemiparesis }\end{array}$ & $\begin{array}{l}\text { Maeda } \\
\text { et al. (30) }\end{array}$ \\
\hline 11 & $\begin{array}{l}\text { Right putaminal hemorrhage } \\
\text { and bleed in all four ventricles }\end{array}$ & Angiogram & $\begin{array}{l}\text { Supraclinoid portion of both internal } \\
\text { carotic arteries }\end{array}$ & Day 17 & No data & $\begin{array}{l}\text { Persistent mild left sided } \\
\text { hemiparesis }\end{array}$ & $\begin{array}{l}\text { Maeda } \\
\text { et al. (30) }\end{array}$ \\
\hline 44 & $\begin{array}{l}\text { IVH of the fourth ventricle, } \\
\text { right lateral ventricle }\end{array}$ & $\begin{array}{l}\text { Cerebral artery } \\
\text { angiography }\end{array}$ & $\begin{array}{l}\text { Left posteroinferior cerebellar artery left } \\
\text { and right vertebral arteries }\end{array}$ & Day 3 & $\begin{array}{l}\text { Hypervolemia with intravenous fluids, induction } \\
\text { of hypertension with neosynephrine with a mean } \\
\text { arterial blood pressure goal of } 130-140 \mathrm{mmHg} \\
\text { for } 4 \text { days with clear resolution of neurological } \\
\text { symptoms in response to it }\end{array}$ & $\begin{array}{l}\text { Left facial paralysis, left } \\
\text { beating nystagmus, vertigo, } \\
\text { slurred speech }\end{array}$ & $\begin{array}{l}\text { Dull and } \\
\text { Torbey (31) }\end{array}$ \\
\hline 26 & IVH in the right lateral ventricle & $\begin{array}{l}\text { Cerebral } \\
\text { angiography }\end{array}$ & Middle and anterior cerebral arteries & Day 17 & No data & $\begin{array}{l}\text { Left homonymous } \\
\text { hemianopsia }\end{array}$ & $\begin{array}{l}\text { Kobayashi } \\
\text { et al. (32) }\end{array}$ \\
\hline 31 & $\begin{array}{l}\text { IVH and hemorrhage in the } \\
\text { head of the right caudate } \\
\text { nucleus and the genu of the } \\
\text { corpus callosum }\end{array}$ & $\begin{array}{l}\text { Cerebral } \\
\text { angiography, } \\
\text { transcranial } \\
\text { Doppler } \\
\text { ultrasound }\end{array}$ & Both internal carotid arteries & Day 16 & $\begin{array}{l}\text { Transluminal angioplasty of the right internal } \\
\text { carotid artery with a single-lumen, over-the-wire } \\
\text { balloon catheter with clear effect on vasospasm, } \\
\text { intravenous nimodipine }\end{array}$ & $\begin{array}{l}\text { Left sided hemiparesis, } \\
\text { neuropsychological deficits }\end{array}$ & $\begin{array}{l}\text { Kothbauer } \\
\text { et al. (33) }\end{array}$ \\
\hline
\end{tabular}




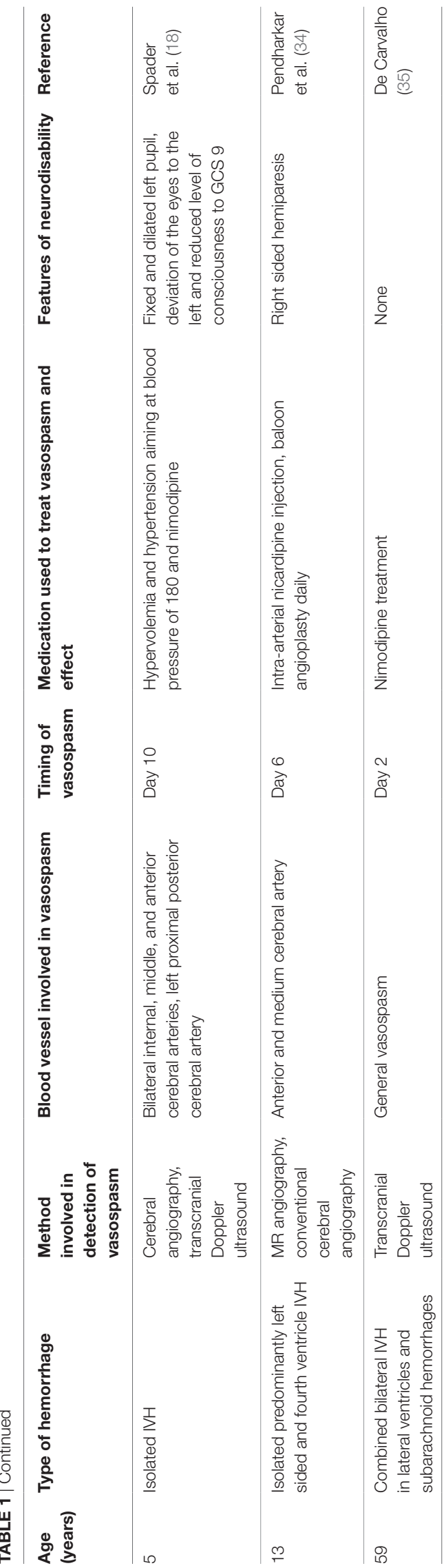

\section{TESTING OF THE HYPOTHESIS}

Before embarking on trials of intervention cerebral vasospasm in neonatal IVH needs to be documented and assessed in longitudinal studies at the timepoints at which post-IVH cerebral vasospasm has been detected in adults namely at $48 \mathrm{~h}$, between day 4 and 6 and between day 7 and 9 after diagnosis of IVH. To assess the presence of cerebral vasospasm in preterm neonates, non-invasive methods need to be employed. Blood velocity measurements using transcranial Doppler ultrasound can be used in preterm neonates for detection of cerebral vasospasm. The Lindegaard ratio (described earlier) can again be used to diagnose vasospasm (40). The long-term neurological outcome needs to be compared between neonates with and without cerebral vasospasm detected by this method.

Future studies could measure NO metabolites and IL- 1 in the CSF of preterms with IVH serially (e.g., daily) to determine whether the increase (IL-1) or decrease (NO metabolites) in concentration over time could predict the crossing of a "vasospasmogenic threshold" and thus predict cerebral vasospasm. The absolute concentration could in this context also be correlated with the time to evolution of the vasospasm. Heme or its metabolite bilirubin could be measured at the same time to assess its predictive value for vasospasm and the need for preventative intervention.

\section{IMPLICATIONS OF A CONFIRMATION OF THE HYPOTHESIS}

The most important intervention with significant future potential in reduction and prevention of cerebral vasospasm and its associated neurodisability in neonatal IVH is rapid removal of the accumulated blood by all available means. Delayed removal of a perivascular clot in SAH has been demonstrated to be associated with a lack of resolution of vasospasm since clot removal up to 3 days after hemorrhage reduced vasospasm, but after 5 days, it had little influence (41). Drainage, irrigation, and fibrinolytic therapy (DRIFT) in infants with posthemorrhagic ventricular dilatation followed up until 2 years of age showed the following results: of 39 infants assigned to DRIFT, 21 (54\%) died or were severely disabled vs 27 of $38(71 \%)$ in the standard group (adjusted odds ratio 0.25 [95\% confidence interval: 0.08-0.82]). Among the survivors, 11 of 35 (31\%) in the DRIFT group had severe cognitive disability vs 19 of 32 (59\%) in the standard group (adjusted odds ratio: 0.17 [95\% confidence interval: 0.05-0.57]). Median Mental Development Index was 68 with DRIFT and $<50$ with standard care. Severe sensorimotor disability was not significantly reduced (42). Some of this effect may have been due to treatment of the evolving hydrocephalus but removal of the ongoing heme sources scavenging $\mathrm{NO}$ and causing ongoing release of vasospasm causing IL-1 may have been crucial. To assess the impact of the DRIFT intervention in all grades of IVH, ultrasound Doppler studies assessing correlates of vasospasm before and after the intervention need to be explored and put into relationship to neurological long-term outcome. At the same time, one could measure peripheral blood glial fibrillary acidic protein levels-a sensitive marker of brain injury-before and 
after the intervention and in controls without the intervention. Neuroendoscopic lavage for clot removal has been successfully and safely employed and shown to be possibly superior to DRIFT related procedures in preventing hydrocephalus and warrants further study (43).

Optimization of cerebral perfusion pressure by hypervolemia with intravenous fluids and induction of hypertension with neosynephrine appears to be an important auxiliary measure to be put into place as anecdotal evidence suggests (see Table 1).

As the listed case reports demonstrate larger cerebral arteries can be involved in IVH-associated vasospasm. Angioplasty has been successful in resolution of vasospasm in SAH and IVH $(44,45)$ and needs to be explored in established vasospasm in preterm neonates.

Case reports support the future use of peripheral intravenous infusion of the NO donor molsidomine, and intrathecal application of nitroprusside sodium in patients with IVH because they appear to reduce cerebral vasospasm (46).

To support DRIFT once established as an effective intervention intrathecal adjuvant high-dose vasodilator, anti-inflammatory, and hemoglobin and heme scavenging treatments should be employed using slow release preparations where available. Such drugs could include tissue plasminogen activator or NO donors in isolation or in combination (47) and heme scavengers haemopexin and haptoglobin $(48,49)$. One may argue that conclusions from the data on vasospasm in IVH in adults are not transferable to preterm neonates because inflammation may be different in the fetus and therefore the preterm infant due to the immaturity of the immune system. It is, however, unclear whether this immaturity affects IL-1 production following IVH: experiments employing lipopolysaccharide-induced IL-1 secretion from very low birth weight infants (VLBWI) and from newborns after 30 weeks gestation in comparison to adults showed a diminished ex vivo LPS stimulated IL-1 beta secretion into whole blood in VLBWI (50). In line with these findings Brochu et al. found a weaker IL-1beta response in the immature compared to the more mature term-like brain. In this rat model, as well as in human preterm newborns, the IL- $1 \mathrm{~b}$ response takes place mainly in deep white matter that corresponds to the area of vulnerability to IVH. Prematurity may be associated with an imbalance of the IL-1beta/IL-1receptor antagonist (IL-1-Ra) ratio due to a

\section{REFERENCES}

1. Bolisetty S, Dhawan A, Abdel-Latif M, Bajuk B, Stack J, Lui K. New South Wales and Australian capital territory neonatal intensive care units' data collection intraventricular hemorrhage and neurodevelopmental outcomes in extreme preterm infants. Pediatrics (2014) 133:55-62. doi:10.1542/peds.2013-0372

2. Lou HC. Perinatal hypoxic-ischemic brain damage and intraventricular hemorrhage. A pathogenetic model. Arch Neurol (1980) 37:585-7. doi:10.1001/ archneur.1980.00500580081017

3. Mukerji A, Shah V, Shah PS. Periventricular/intraventricular hemorrhage and neurodevelopmental outcomes: a meta-analysis. Pediatrics (2015) 136:1132-43. doi:10.1542/peds.2015-0944

4. Burstein J, Papile LA, Burstein R. Intraventricular hemorrhage and hydrocephalus in premature newborns: a prospective study with CT. AJR Am J Roentgenol (1979) 132:631-5. doi:10.2214/ajr.132.4.631

5. Szpecht D, Wiak K, Braszak A, Szymankiewicz M, Gadzinowski J. Role of selected cytokines in the etiopathogenesis of intraventricular haemorrhage reduction of upregulation of IL-1Ra expression $(51,52)$. This may mean a reduced expression of IL-1 in response to stimuli is at least partially offset by an even more reduced anti-IL-1 response. Whole genome analysis of the transcriptome of the fetal inflammatory response syndrome in umbilical cord blood from preterm neonates with fetal inflammatory response syndrome revealed on microarray analysis of leukocyte RNA, a substantial degree of similarity with the systemic inflammatory response syndrome in adults (53).

To inhibit the neuroinflammation associated with hemeinduced activation of inflammasomes and with increased IL-1 production leading to an increased risk of vasospasm one could treat the affected newborns with inflammasome inhibitors like telmisartan which has been shown to reduce NLRP3 activity and IL-1 levels and associated cerebral injury (54-56). These anti-inflammatory interventions could be safe in all degrees of severity of IVH but need to be first explored in animal studies. The intervention to reduce vasospasm-associated neurodisability should be employed as soon as an IVH is detected to act as effective preventative. Such animal experiments also need to explore the effect of intra-arterial verapamil, which has been shown to relieve vasospasm in a patient with IVH (see Table 1). All drug treatment interventions including intrathecal application could be assessed in the preterm rabbit model of glycerol-induced IVH, which has been developed for this purpose (57). Such studies could analyze the impact of inflammasome inhibitors and NO donors on transcranial Doppler-ultrasonographic evidence of vasospasm on neurological symptoms and histological pattern of brain injury.

\section{AUTHOR CONTRIBUTIONS}

ME conceived the hypothesis, drafted the outline of the review, and wrote the final version of the manuscript. SC made substantial contributions to the acquisition of data and revision. Both authors gave the final approval of the version to be published, agreed to be accountable for all aspects of the work in ensuring that analysis or interpretation of data for the work, and agreed to be accountable for all aspects of the work in ensuring that questions related to the accuracy or integrity of any part of the work are appropriately investigated and resolved.

in preterm newborns. Childs Nerv Syst (2016) 32:2097-103. doi:10.1007/ s00381-016-3217-9

6. Patra K, Wilson-Costello D, Taylor HG, Mercuri-Minich N, Hack M. Grades I-II intraventricular hemorrhage in extremely low birth weight infants: effects on neurodevelopment. JPediatr (2006) 9:169-73. doi:10.1016/j. jpeds.2006.04.002

7. Siuta M, Zuckerman SL, Mocco J. Nitric oxide in cerebral vasospasm: theories, measurement, and treatment. Neurol Res Int (2013) 2013:972417. doi:10.1155/2013/972417

8. Sehba FA, Schwartz AY, Chereshnev I, Bederson JB. Acute decrease in cerebral nitric oxide levels after subarachnoid hemorrhage. J Cereb Blood Flow Metab (2000) 20:604-11. doi:10.1097/00004647-200003000-00018

9. Toda N, Ayajiki K, Okamura T. Cerebral blood flow regulation by NO: recent advances. Pharmacol Rev (2009) 61:62-97. doi:10.1124/pr.108.000547

10. Dutra FF, Alves LS, Rodrigues D, Fernandez PL, de Oliveira RB, Golenbock DT, et al. Hemolysis-induced lethality involves inflammasome activation by heme. Proc Natl Acad Sci U S A (2014) 111:E4110-8. doi:10.1073/pnas.1405023111 
11. Eisenhut M. Vasospasm in cerebral inflammation. Int J Inflamm (2014) 2014:509702014. doi:10.1155/2014/509707

12. Ellison VJ, Mocatta TJ, Winterbourn CC, Darlow BA, Volpe JJ, Inder TE. The relationship of CSF and plasma cytokine levels to cerebral white matter injury in the premature newborn. Pediatr Res (2005) 57:282-6. doi:10.1203/01. PDR.0000148286.53572.95

13. Adler I, Batton D, Betz B, Bezinque S, Ecklund K, Junewick J, et al. Mechanisms of injury to white matter adjacent to a large intraventricular hemorrhage in the preterm brain. J Clin Ultrasound (2010) 38:254-8. doi:10.1002/jcu.20683

14. Lekic T, Klebe D, Poblete R, Krafft PR, Rolland WB, Tang J, et al. Neonatal brain hemorrhage $(\mathrm{NBH})$ of prematurity: translational mechanisms of the vascular-neural network. Curr Med Chem (2015) 22:1214-38. doi:10.2174/09 29867322666150114152421

15. Phan K, Moore JM, Griessenauer CJ, Xu J, Teng I, Dmytriw AA, et al. Ultraearly angiographic vasospasm after aneurysmal subarachnoid hemorrhage: a systematic review and meta-analysis. World Neurosurg (2017) 102:632-8.e1. doi:10.1016/jwneu.2017.03.057

16. Regula JU, Schill J, Ringleb PA, Sykora M. Cerebral vasospasm and delayed cerebral ischemia in intraventricular haemorrhage. Neurocrit Care (2014) 20:460-5. doi:10.1007/s12028-013-9897-z

17. Kiphuth IC, Huttner HB, Breuer L, Engelhorn T, Schwab S, Koehrmann M. Vasospasm in intracerebral haemorrhage with ventricular involvement: a prospective pilot transcranial Doppler sonography study. Cerebrovasc Dis (2011) 32:420-5. doi:10.1159/000330652

18. Spader HS, Doberstein CE, Rao AJ, Jayaraman MV. Central fever as an early predictor of vasospasm in a child with isolated intraventricular haemorrhage. Clin Neurol Neurosurg (2011) 113:146-9. doi:10.1016/j.clineuro.2010.09.005

19. Basu S, Agarwal P, Anupurba S, Shukla R, Kumar A. Elevated plasma and cerebrospinal fluid interleukin-1 beta and tumor necrosis factor-alpha concentration and combined outcome of death or abnormal neuroimaging in preterm neonates with early-onset clinical sepsis. J Perinatol (2015) 35:855-61. doi:10.1038/jp.2015.86

20. Black PM. Hydrocephalus and vasospasm after subarachnoid haemorrhage from ruptured intracranial aneurysms. Neurosurgery (1986) 18:12-6. doi:10.1227/00006123-198601000-00003

21. Liszczak TM, Varsos VG, Black PM, Kistler JP, Zervas NT. Cerebral arterial constriction after experimental subarachnoid haemorrhage is associated with blood components within the arterial wall. J Neurosurg (1983) 58:18-26. doi:10.3171/jns.1983.58.1.0018

22. Mestan KK, Marks JD, Hecox K, Huo D, Schreiber MD. Neurodevelopmental outcomes of premature infants treated with inhaled NO. N Engl J Med (2005) 353:23-32. doi:10.1056/NEJMoa043514

23. Patrianakos-Hoobler AI, Marks JD, Msall ME, Huo D, Schreiber MD. Safety and efficacy of inhaled NO treatment for premature infants with respiratory distress syndrome: follow-up evaluation at early school age. Acta Paediatr (2011) 100:524-8. doi:10.1111/j.1651-2227.2010.02077.x

24. Hirtz DG, Weiner SJ, Bulas D, DiPietro M, Seibert J, Rouse DJ, et al. Antenatal magnesium and cerebral palsy in preterm infants. J Pediatr (2015) 167:834-9. doi:10.1016/j.jpeds.2015.06.067

25. Yanaka K, Hyodo A, Tsuchida Y, Yoshii Y, Nose T. Symptomatic cerebral vasospasm after intraventricular hemorrhage from ruptured arteriovenous malformation. Surg Neurol (1992) 38:63-7. doi:10.1016/0090-3019(92)90214-8

26. Park BS, Won YS, Choi CS, Kim BM. Severe symptomatic vasospasm following intraventricular hemorrhage from arteriovenous fistula. J Korean Neurosurg Soc (2009) 45:300-2. doi:10.3340/jkns.2009.45.5.300

27. Gerard E, Frontera JA, Wright CB. Vasospasm and cerebral infarction following isolated intraventricular hemorrhage. Neurocrit Care (2007) 7:257-9. doi:10.1007/s12028-007-0057-1

28. Yokobori S, Watanabe A, Nakae R, Onda H, Fuse A, Kushimoto S, et al. Cerebral vasospasms after intraventricular hemorrhage from an arteriovenous malformation: case report. Neurol Med Chir (Tokyo) (2010) 50:320-3. doi:10.2176/nmc.50.320

29. Tseng W-L, Tsai Y-H. Vasospasm after intraventricular hemorrhage caused by arteriovenous malformation. Asian J Neurosurg (2015) 10:114-6. doi:10.4103/1793-5482.154984

30. Maeda K, Kurita H, Nakamura T, Usui M, Tsutsumi K, Morimoto T, et al. Occurrence of severe vasospasm following intraventricular hemorrhage from an arteriovenous malformation. Report of two cases. J Neurosurg (1997) 87:436-9. doi:10.3171/jns.1997.87.3.0436
31. Dull C, Torbey MT. Cerebral vasospasm associated with intraventricular hemorrhage. Neurocrit Care (2005) 3:150-2. doi:10.1385/NCC:3:2:150

32. Kobayashi M, Takayama H, Milhara B, Kawase T. Severe vasospasm caused by repeated intraventricular haemorrhage from small arteriovenous malformation. Acta Neurochir (Wien) (2002) 144:405-6. doi:10.1007/s00701 0200059

33. Kothbauer K, Schroth G, Seiler RW, Do DD. Severe symptomatic vasospasm after rupture of an arteriovenous malformation. AJNR Am J Neuroradiol (1995) 16:1073-5.

34. Pendharkar AV, Guzman R, Dodd R, Cornfield D, Edwards MS. Successful treatment of severe cerebral vasospasm following hemorrhage of an arteriovenous malformation. Case report. J Neurosurg Pediatr (2009) 4:266-9. doi:10.3171/2009.4.PEDS09126

35. DeCarvalho JC, Machin FJ, Manzanera LS, AndaluzJB, Nogues SH, Soriano NP, et al. Intraventricular haemorrhage after dural fistula embolization. Rev Bras Anestesiol (2017) 67:199-204. doi:10.1016/j.bjan.2016.09.002

36. Barrington KJ, Finer N, Pennaforte T. Inhaled NO for respiratory failure in preterm infants. Cochrane Database Syst Rev (2017) 3(1):CD000509. doi:10.1002/14651858.CD000509.pub5

37. Peliowski A. Canadian Paediatric Society, fetus and newborn committee inhaled NO use in newborns. Paediatr Child Health (2012) 17:95-100. doi:10.1093/pch/17.2.95

38. Holcberg G, Sapir O, Hallak M, Alaa A, Shorok HY, David Y, et al. Selective vasodilator effect of magnesium sulfate in human placenta. Am J Reprod Immunol (2004) 51:192-7. doi:10.1111/j.1600-0897.2004.00115.x

39. Qureshi AI, Palesch YY, Barsan WG, Hanley DF, Hsu CY, Martin RL, et al. Intensive blood-pressure lowering in patients with acute cerebral hemorrhage. N Engl J Med (2016) 375:1033-43. doi:10.1056/NEJMoa1603460

40. Lindegaard K-F, Nornes H, Bakke SJ, Sorteberg W, Nakstad P. Cerebral vasospasm diagnosis by means of angiography and blood velocity measurements. Acta Neurochir (1989) 100:12-24. doi:10.1007/BF01405268

41. Stoodley M, Macdonald RL, Weir B, Marton LS, Johns L, Du Zhang Z, et al. Subarachnoid hemorrhage as a cause of an adaptive response in cerebral arteries. J Neurosurg (2000) 93(3):463-70. doi:10.3171/jns.2000.93.3.0463

42. Whitelaw A, JaryS, Kmita G, WroblewskaJ,Musialik-SwietlinskaE, Mandera M, et al. Randomized trial of drainage, irrigation and fibrinolytic therapy for premature infants with posthemorrhagic ventricular dilatation: developmental outcome at 2 years. Pediatrics (2010) 125:852-8. doi:10.1542/peds. 2009-1960

43. Schulz M, Bührer C, Pohl-Schickinger A, Haberl H, Thomale UW. Neuroendoscopic lavage for the treatment of intraventricular hemorrhage and hydrocephalus in neonates. J Neurosurg Pediatr (2014) 13:626-35. doi:10.3171/2014.2.PEDS13397

44. Barnwell SL, Higashida RT, Halbach VV, Dowd CF, Wilson CB, Hieshima GB. Transluminal angioplasty of intracerebral vessels for cerebral arterial spasm: reversal of neurological deficits after delayed treatment. Neurosurgery (1989) 25:424-9. doi:10.1227/00006123-198909000-00017

45. Zubkow YN, Nikiforov BM, Shustin VA. Balloon catheter technique for dilatation of constricted cerebral arteries after aneurysmal SAH. Acta Neurochir (Wien) (1984) 70:65-79. doi:10.1007/BF01406044

46. Ehlert A, Manthei G, Hesselmann V, Mathias K, Bein B, Pluta R. A case of hyperacute onset of vasospasm after aneurysmal subarachnoid hemorrhage and refractory vasospasm treated with intravenous and intraventricular NO: a mini review. World Neurosurg (2016) 91:673.e11-8. doi:10.1016/j. wneu.2016.04.047

47. Omeis I, Neil JA, Murali R, Abrahams JM. Treatment of cerebral vasospasm with biocompatible controlled-release systems for intracranial drug delivery. Neurosurgery (2008) 63:1011-9. doi:10.1227/01.NEU.0000327574. 32000.9A

48. Schaer DJ, Buehler PW, Alayash AI, Belcher JK, Vercellotti GM. Haemolysis and free hemoglobin revisited: exploring hemoglobin and hemin scavengers as a novel class of therapeutic proteins. Blood (2013) 121:1276-84. doi:10.1182/ blood-2012-11-451229

49. Vinchi F, de Franceschi L, Ghigo A, Townes T, Cimino J, Silengo L, et al. Hemopexin therapy improves cardiovascular function by preventing hemeinduced endothelial toxicity in mouse models of hemolytic diseases. Circulation (2013) 127:1317-29. doi:10.1161/CIRCULATIONAHA.112.130179

50. Foerster-WaldlE,SadeghiK, TamandlD, GerholdB, HallwirthU,RohrmeisterK, et al. Monocyte toll-like receptor 4 expression and LPS-induced cytokine 
production increase during gestational aging. Pediatr Res (2005) 58:121-4. doi:10.1203/01.PDR.0000163397.53466.0F

51. Brochu ME, Girard S, Lavoie K, Sébire G. Developmental regulation of the neuroinflammatory responses to LPS and/or hypoxia-ischemia between preterm and term neonates: an experimental study. J Neuroinflammation (2011) 8:55. doi:10.1186/1742-2094-8-55

52. Girard S, Sebire G, Kadhim H. Proinflammatory orientation of the interleukin 1 system and downstream induction of matrix metalloproteinase 9 in the pathophysiology of human perinatal white matter damage. J Neuropathol Exp Neurol (2010) 69:1116-29. doi:10.1097/NEN.0b013e3181f971e4

53. Madsen-Bouterse SA, Romero R, Tarca AL, Kusanovic JP, Espinoza J, Kim CJ, et al. The transcriptome of the fetal inflammatory response syndrome. Am J Reprod Immunol (2010) 63:73-92. doi:10.1111/j.1600-0897.2009. 00791.x

54. Wei X, Hu CC, Zhang YL, Yao SL, Mao WK. Telmisartan reduced cerebral edema by inhibiting NLRP3 inflammasome in mice with cold brain injury. JHuazhong Univ Sci Technolog Med Sci (2016) 36:576-83. doi:10.1007/ s11596-016-1628-1

55. Cao G, Jiang N, Hu Y, Zhang Y, Wang G, Yin M, et al. Ruscogenin attenuates cerebral ischemia-induced blood-brain barrier dysfunction by suppressing
TXNIP/NLRP3 inflammasome activation and the MAPK pathway. Int J Mol Sci (2016) 17:1418. doi:10.3390/ijms17091418

56. Eisenhut M. Increased activity of inflammasomes as osmosensors as cause of cerebral edema in diabetic ketoacidosis. J Syst Integr Neurosci (2016) 2:210-2. doi:10.15761/JSIN.1000137

57. Ley D, Romantsik O, Vallius S, Sveinsdottir K, Sveinsdottir S, Agyemang AA, et al. High presence of extracellular haemoglobin in the periventricular white matter following preterm intraventricular hemorrhage. Front Physiol (2016) 7:330. doi: $10.3389 /$ fphys.2016.00330

Conflict of Interest Statement: The authors declare that the research was conducted in the absence of any commercial or financial relationships that could be construed as a potential conflict of interest.

Copyright $(2017$ Eisenhut and Choudhury. This is an open-access article distributed under the terms of the Creative Commons Attribution License (CC BY). The use, distribution or reproduction in other forums is permitted, provided the original author(s) or licensor are credited and that the original publication in this journal is cited, in accordance with accepted academic practice. No use, distribution or reproduction is permitted which does not comply with these terms. 